\title{
THE MAKINGS OF DYNAMITE
}

\author{
Alyza Taguilaso \\ alyza.taguilaso@gmail.com
}

\begin{abstract}
About the Author
Alyza Taguilaso recently graduated Doctor of Medicine at the University of the East Ramon Magsaysay Memorial Medical Center, Inc. Prior to this, she obtained her degree in Biology from the Ateneo de Manila University. Her poems have appeared in High Chair, Stone Telling Magazine, Paper Monster Press, the Kritika Kultura Anthology of New Philippine Writing in English, and Under The Storm: An Anthology of Contemporary Philippine Poetry. Alyza maintains a writing journal at Speaking In Hushed Tones.
\end{abstract}




\section{Purity Report}

To save a failing heart with the makings of dynamite. To plough past a forest set to white flame, knees digging deeper into soot, eyes seconds from being singed into blindness. To hear voices. To witness wars waged with weapons, words, wives. To grant anger a beautiful face, its eyes draped in perfect blue: deception the quiet ocean waiting for the sound of bare feet dancing on its surface. To slither from paradise and down the rabbit hole: arms ready to embrace the soil, the abundance of worms wriggling from stray apples, a wayward rib fractured from the impact. To harness planets with songs of a star on the verge of collapse. To converse with collisions and silver-eyed angels, wings swollen with grace. To believe in an absent god. To believe in belief itself, the difficult necessity of faith. To love and last long enough. To risk loss and becoming lost from too much longing. To feel hunger and turn the other way. To be named, find your place among all other animals - opposable thumbs, sharpened incisors, soft skin the only barrier to a weak and human core. To drown desire. To touch the tender cheeks, bruised from belief, all those kisses from an army of locusts.

To wash off the psalms painted on palms, cold and upturned.

To cast the first stone. 


\section{Pathos}

I worry I do not have enough sadness left

to keep me vigilant. I wish this were about an old love leaving me

to weep, or a description of the shape my father's face took

that day he was unable to recognize his own daughters

a decade after leaving: the world suddenly without a single word

for forgiveness. Instead this is how my heart grew

stronger but stranger spending a year seeing people die.

After a while, the wailing sounds the same, making it easier

to spot a pulse. All questions given the same answer: This is how much you have left. Hope an inversion amidst a parade

of flat lines on a long white ribbon: the faint $l u b$ of a feeble heart fighting a colony of clogged arteries may also spell submission

to all the medicines made to run, deceiving

the body into believing it's still alive. This is no different 
from everything else. You don't ask to leave your children. You don't ask to love

someone who will never return the favor. You don't ask for needles to harvest your blood. You don't ask for tubes and a metal box

in place of your shrunken lungs. You don't ask for a hole in a newborn's heart even if that's the one thing that might keep her blood flowing:

much too tiny and pale, barely a person but with lips gasping for air, gathering enough sound to cry for the first time. 


\section{Contentment}

It surprises me how we fell into each other's lives

in the patient span of seven years. We began with resisting

the pull of loneliness. We prayed

to the gods and let our bodies be eased

across easier bodies: all those people who demanded so little

for slivers of affection. Whose name do you find yourself calling

amidst those seasons of entropy? Remember the taste of all our secrets

done right? I fervently believed my heart

a caged animal - its hooves pounding songs

of longing: the sweet lack

of self-control. How you stood

unflinching when I confessed my eyes were blind

to the color of kindness, saturated with sighing wavelengths

in a universe eager to keep its distance. How you held me

as I shook, frightened of all things good. Your hands steady

as my bones rearranged themselves to accommodate this enormity

called love. Our shadows titans resting

against the white wall of your room.

I reach out to touch your face and my limbs grow wings

wide enough to map all the landscapes of happiness

we planted in our sleep. All those golden seeds blooming into beauty, certain to rip our bodies apart. 


\section{Barter}

perhaps if borrowing is not natural there is some use in giving. - "Objects" Gertrude Stein

To save someone, I was given a million ways

our bodies die. For anger

I was given art. For hunger,

persistence and a talent

for describing pain. I had a friend

who could listen to all the voices of air, tasting

colors at the tip of her tongue. Red was milk, yellow a fruit

somewhere along the borders of despair, cyan the patient salt

scraping fresh wounds. I set my happiness afloat

inside a glass case, frozen and asleep in exchange for a pair of eyes:

myopic but brighter than a dying star. The sound of rain became my song,

my lips found ways to plant scars that blossomed on his face. For radiance,

I gave caution over to memory. For the names of all the gods, I let my faith turn

to dust. For a room with soft corners and petals at the tips of my fingers, the reflex

of fear

of lightning and distant voices. For my sadness I was given nothing

but another day to continue living - hope a fist,

clenched and beating inside a garden of bones. 


\section{Origins}

I am from a tall house painted dirty orange and outlined in white: tiny pebble placed in the capital of cat-sized alley rats, gravel, asphalt, and floodwater.

I am from smoke left to lodge in a thousand pink-gray lungs: embers dormant but ready to burn, bloom into fire.

I am from postcards sent through ten years of loneliness: Dragons, dolls, stacks of books. Photograph of a famous monument. Fashion magazine cover circa 1937. Handwriting hurried in uppercase; the absence of a return address; each missive ending with a request: Answer me.

I am from the various versions of home: Asakusa and its quiet mornings, Brooklyn with secrets seamlessly strewn between side streets, Culasi's empty beaches, Siquijor and the ghosts hanging their weightless bodies on souvenirs, Bandung's cold breath charting maps upon maps to getting lost, Cubao and its bowels lined with generic drugstores, signs in triple neon, and all those clothes aching to be worn once more.

I am from dermal folds interlacing, faint lines, fault lines.

I am from mother's misgivings.

I am from father's persistence - presents purchased on borrowed money. A catalog of cocksure smiles offering alternatives for contentment. How he could easily sell you a shipwreck if he desired.

I am from grandmother's medications: Cyclophosphamide, Vincristine, Methotrexate. How her body withered silently in a span of 6 months and in her dying taught me which questions never to ask.

I am from a bloodline rife with disease: Diabetes, hypertension, asthma, manic depression, schizophrenia - an inheritance blessed with genes that made for brilliant stories but difficult lives.

I am from the atomic bomb, the retractable folding knife, the scalpel, the syringe and its upturned bevel.

I am from whatever the universe could give when gods were not enough: nitrogen, helium, hydrogen, aluminum, yttrium. Titanium, nickel, cadmium, tungsten. 
Molecules bustling against each other, burning and brimming from bodies eager to burst.

I am from dust, ash, and all its nameless variants. Sea salt and sand: easing its way to where you are, a single grain at a time. 